\title{
Organic acid composition and consumer acceptability of fermented fish produced from black tilapia (Oreochromis mossambicus) and Javanese carp (Puntius gonionotus) using natural and acid-assisted fermentation
}

\author{
1, ${ }^{*}$ Ezzat, M.A., ${ }^{1}$ Ghazali, M.H., ${ }^{1}$ Roselina, K. and ${ }^{2}$ Zare, D. \\ ${ }^{1}$ Faculty of Food Science and Technology, Universiti Putra Malaysia, 43400 UPM, Serdang, Selangor, \\ Malaysia \\ ${ }^{2}$ Iranian Research Organization for Science and Technology, Tehran, Iran
}

\begin{abstract}
Article history:
Received: 13 October 2020

Received in revised form: 25

November 2020

Accepted: 5 February 2021

Available Online: 21 March

2021
\end{abstract}

Keywords:

Fermented fish,

Ikan pekasam,

Organic acid profile,

Consumer acceptability,

Traditional products

DOI:

https://doi.org/10.26656/fr.2017.5(2).583

\begin{abstract}
Ikan pekasam is an example of traditional fermented food products in Malaysia, prepared from freshwater fish such as black tilapia (Oreochromis mossambicus) and Javanese carp (Puntius gonionotus), salt and ground roasted rice, which is added as the only source of carbohydrate. However, some producers add tamarind (Tamarindus indica) pulp and/or dried slices of Garcinia atroviridis to assist the fermentation process. In this study, there was no correlation detected between $\mathrm{pH}$ value, titratable acidity (\% lactic acid), salt concentration, organic acid composition and the consumer acceptability of ikan pekasam commercial samples made of black tilapia as well as Javanese carp. The organic acid composition in both natural and acid-assisted fermented ikan pekasam from black tilapia and Javanese carp were compared. The results obtained showed that lactic acid was the major organic acid detected, followed by succinic acid and acetic acid. The addition of tartaric and/or garcinia acids was proven to reduce the fermentation time. Therefore, the addition of acid has assisted the fermentation process by increasing the total organic acid content, mainly lactic acid. Moreover, the 9-point hedonic scale showed that ikan pekasam made of Javanese carp had higher overall acceptability due to tender flesh/muscle texture compared to black tilapia regardless of the fermentation process and organic acid content.
\end{abstract}

\section{Introduction}

Fermentation represents one of the oldest preservation techniques and is the most vital traditional method of food processing in the world (Rhee et al., 2011; Agyei et al., 2020). Ikan pekasam is a Malaysian term for fermented fish that has been fermented using ground roasted (uncooked) rice, and salt, often served with hot rice after being deep-fat fried. Traditionally, ikan pekasam is made of freshwater fish such as black tilapia (Oreochromis mossambicus) and Javanese carp (Puntius gonionotus) by mixing the eviscerated and cleaned fish with approximately $30 \%(\mathrm{w} / \mathrm{w})$ of salt for 3 to 14 days at ambient temperatures (Department of Fisheries Malaysia, 2014). Then, the fish is rinsed and mixed with ground roasted rice and left to ferment at ambient temperature for up to two weeks in a closed container.

During ikan pekasam natural fermentation, only ground roasted rice is added as the source of carbohydrate. However, aside from rice, some typical food acidifier such as tamarind (Tamarindus indica) pulp or dried slices of Garcinia atroviridis (Department of Fisheries Malaysia, 2014) are also added to accelerate the fermentation process, known as acid-assisted fermentation. Tamarind pulp contains tartaric acid (Bhadoriya et al., 2011; Natukunda et al., 2016), while the major organic acid in $G$. atroviridis is garcinia acid $\left(\mathrm{C}_{6} \mathrm{H}_{6} \mathrm{O}_{7}\right)$ which is the lactone form of hydroxycitric acid (free lactone form, $\mathrm{C}_{6} \mathrm{H}_{6} \mathrm{O}_{8}$ ) (Jayaprakasha and Sakariah, 2002).

Lactic acid is mostly produced by lactic acid bacteria (LAB) and some types of filamentous fungi (Litchfield, 1996). LAB has the property of breaking down carbohydrate source to produce lactic acid (Riebroy et al., 2004; Rhee et al., 2011), particularly in traditional fermented food. During natural fermentation, LAB produces two types of metabolites, which are homofermentative and heterofermentative. Only lactic acid has been produced as a single product by homofermentative LAB. On the other hand, besides lactic acid, the heterofermentative $\mathrm{LAB}$ also produces 
other products such as ethanol, diacetyl, formate, acetoin or acetic acid, and $\mathrm{CO}_{2}$ (John et al., 2007; Reddy et al., 2008).

A study by Ezzat et al. (2015) reported that ikan pekasam made of black tilapia and Javanese carp that had undergone either natural or acid-assisted fermentation did not significantly affect the amino acid, biogenic amine and urocanic acids of the products. However, the histamine contents did not exceed $100 \mathrm{mg} /$ $\mathrm{kg}$, which was the maximum limit allowed by Good Manufacturing Practice (GMP) (Lehane and Olley, 2000; Hu et al., 2007). This low histamine level was similar to the numerous fish product in Malaysia as studied by Zare et al. (2015), except for dried salted fish. Moreover, other than in ikan pekasam, histamine $(1694 \mathrm{mg} / \mathrm{kg})$, putrescine $(684 \mathrm{mg} / \mathrm{kg})$, cadaverine $(1795 \mathrm{mg} / \mathrm{kg})$, transUCA $(1.38 \mathrm{mg} / \mathrm{kg})$ and $c i s-U C A(2.26 \mathrm{mg} / \mathrm{kg})$ were also found in Indian mackerel after two days in storage at room temperatures (Zare et al., 2013). Despite its growing popularity, not many studies had been reported on the fermentation processes that were generally used to produce ikan pekasam in Malaysia. Therefore, the present study was conducted to determine the organic acid composition and to assess consumer acceptance of commercial ikan pekasam produced by natural and acidassisted fermentation processes.

\section{Materials and methods}

\subsection{Material}

Ikan pekasam samples contain six samples of black tilapia (90 to $105 \mathrm{~g}$ each) and nine samples of Javanese carp (50 to $75 \mathrm{~g}$ each) that were purchased from markets and small-scale producers in various parts of Peninsular Malaysia. Each fish was sealed in separate plastic bags. The purchased ikan pekasam samples were fermented for 14 to 30 days and contain 10 to $15 \%$ salt, with eight of the samples (three from black tilapia and five from Javanese carp) have undergone acid-assisted fermentation process. The samples were coded with the letters A to O (Table 1) for reference purpose and kept in a cooler box containing crushed ice before being transferred to $\mathrm{a}-20^{\circ} \mathrm{C}$ freezer at the laboratory.

Purchases of chemicals at analytical grade were made, with the percentages in parentheses to indicate the purity of the acids, listed as follow. Lactic acid (85\%) was acquired from JT. Baker (Central Valley, USA), while oxalic acid (100\%), tartaric acid (99\%), and citric acid (99\%) were bought from Fisher Scientific (Rochester, NY, USA). Formic acid (95\%), garcinia acid (lactone form) (95\%), hydroxycitric acid (free lactone form) (95\%), malic acid (99\%), L-pyroglutamic acid (99\%), and succinic acid (99\%) were obtained from Sigma Aldrich (St. Louis, MO, USA). Acetic acid $(100 \%)$ and fumaric acid $(99 \%)$ were purchased from Merck (Darmstadt, Germany). Also, High-Performance Liquid Chromatography (HPLC) grade acetonitrile and methanol were purchased from Merck (Darmstadt, Germany). The double-distilled deionized water used for HPLC analysis was from the Milli-Q system (Millipore, Billerica, MA, USA).

Table 1. Sample codes and background information of ikan pekasam samples with different fermentation processes

\begin{tabular}{|c|c|c|c|c|}
\hline \multirow{2}{*}{ Sample Code } & Location of purchase & Substrates & Salting Perio & Fermentation Period \\
\hline & \multicolumn{4}{|c|}{ Black tilapia (Oreochromis mossambicus) } \\
\hline A & Market place & $\begin{array}{l}\text { Salt }+ \text { ground roasted rice }+ \text { tamarind pulp }+ \text { dried } \\
\text { slices of Garcinia atroviridis }\end{array}$ & 1 week & Min. 2 weeks \\
\hline $\mathrm{B}$ & Market place & Salt + ground roasted rice & 1 week & Min. 2 weeks \\
\hline $\mathrm{C}$ & Small-scale producer & Salt + ground roasted rice & 3 days & Min. 2 weeks \\
\hline $\mathrm{D}$ & Market place & Salt + ground roasted rice + tamarind pulp & 1 week & Min. 2 weeks \\
\hline $\mathrm{E}$ & House & Salt + ground roasted rice + tamarind pulp & 3 days & Min. 2 weeks \\
\hline \multirow[t]{2}{*}{$\mathrm{F}$} & House & Salt + ground roasted rice & 1 day & Min. 2 weeks \\
\hline & \multicolumn{4}{|c|}{ Javanese carp (Puntius gonionotus) } \\
\hline G & Market place & $\begin{array}{l}\text { Salt }+ \text { ground roasted rice }+ \text { tamarind pulp }+ \text { dried } \\
\text { slices of Garcinia atroviridis }\end{array}$ & 1 week & Min. 2 weeks \\
\hline $\mathrm{H}$ & Market place & $\begin{array}{l}\text { Salt }+ \text { ground roasted rice }+ \text { tamarind pulp }+ \text { dried } \\
\text { slices of Garcinia atroviridis }\end{array}$ & 1 week & Min. 2 weeks \\
\hline $\mathrm{I}$ & House & Salt + ground roasted rice & 3 days & Min. 2 weeks \\
\hline $\mathrm{J}$ & House & Salt + ground roasted rice + tamarind pulp & 1 week & Min. 2 weeks \\
\hline $\mathrm{K}$ & House & Salt + ground roasted rice & Min. 2 days & Min. 2 weeks \\
\hline $\mathrm{L}$ & House & Salt + ground roasted rice & Min. 4 days & Min. 2 weeks \\
\hline M & Market place & Salt + ground roasted rice + tamarind pulp & 1 week & Min. 2 weeks \\
\hline $\mathrm{N}$ & House & Salt + ground roasted rice & Min. 1 day & Min. 2 weeks \\
\hline $\mathrm{O}$ & Market place & $\begin{array}{l}\text { Salt }+ \text { ground roasted rice }+ \text { tamarind pulp }+ \text { dried } \\
\text { slices of Garcinia atroviridis }\end{array}$ & 1 week & Min. 2 weeks \\
\hline
\end{tabular}




\subsection{Sample preparation}

Before analysis, each ikan pekasam sample was manually cleaned to obtain only the fish muscles, which were then homogenized intermittently for $1 \mathrm{~min}$ in a Waring blender (Waring 32BL79, USA). Representative samples were transferred into round plastic containers, capped, and then stored at $-20^{\circ} \mathrm{C}$. The samples were thawed at room temperature before analysis.

\subsection{Determination of $\mathrm{pH}$, titratable acidity and salt content}

The $\mathrm{pH}$ value and titratable acidity (TA) were determined according to the methods described by AOAC (2010). TA was expressed as \% lactic acid. The salt content was determined using a salt meter (Atago ES $-421,0$ to $28 \%$ salinity, Tokyo, Japan) (Zaman et al., $2011)$ and expressed as \% sodium chloride $(\mathrm{NaCl})$.

\subsection{Organic acid analysis}

The organic acid analysis was conducted using the method as described by Sturm et al. (2003) with a slight modification. Acids were extracted by homogenising 10 $\mathrm{g}$ of the representative sample with $50 \mathrm{~mL}$ of freshly deionised water. Then, the solution was clarified by centrifugation at $8000 \times g$ for 20 mins (Beckman J2-21M/ E, USA). The supernatant was then filtered through a $0.22 \mu \mathrm{m}$ syringe nylon membrane filter (Sartorius, Germany) for HPLC analysis. HPLC analysis was performed in a Waters 2695 Alliance HPLC (Waters Corp., Milford, MA, USA) that was connected to a Waters 2478 two-channel UV detector, two Waters 515 HPLC pumps, an auto-sampler and an online degasser. The chromatographic column used for separation was a Purospher STAR RP18 end-capped column $(250 \times 4.6$ mm I.D., $5 \mu \mathrm{m}$ particle size, from Merck, Darmstadt, Germany connected to a Purospher RP-18e guard column $(4 \times 4 \mathrm{~mm}$ I.D from Merck, Darmstadt, Germany). The mobile phase was $8 \mathrm{mM}$ sulfuric acid in double-distilled deionised water that had been adjusted to $\mathrm{pH} 2.1$. The analysis was carried out isocratically at a flow rate of $0.5 \mathrm{~mL} / \mathrm{min}$, with the injection volume at 1 $\mu \mathrm{L}$. The temperature of the column was at $40^{\circ} \mathrm{C}$ in a column oven, and detection of organic acid was done at $210 \mathrm{~nm}$. The analysis was carried out in triplicates. Organic acids in samples were then identified by comparing the retention times with those of the known standards. The standard organic acid solutions were prepared, ranging from $200 \mathrm{ppm}$ to $1000 \mathrm{ppm}$ in deionised water before being filtered through a $0.22 \mu \mathrm{m}$ nylon membrane filter. The concentration of organic acids in the samples was quantified, and calibration graphs were made by plotting the peak areas against the concentrations injected to HPLC column, which were found to be rectilinear.

Organic acids were also extracted from fresh and dried slices of $G$. atroviridis fruit and tamarind pulp to be analysed, as described above, and compared. The peak that represented garcinia and ascorbic acids in ikan pekasam and fresh, dried slices of $G$. atroviridis fruit were distinguished using a Waters Fraction Collector (Model No. III, Waters Corp., Milford, MA, USA) because of an overlap in retention time. The collector was connected to the HPLC system for organic acid analysis. The fractions were collected based on time mode input parameters after the beginning and end time of peak detection we identified (using the HPLC software system). For each sample, ten runs of fractionation were performed to obtain sufficient material for further analysis. Subsequently, the fractions were injected into the HPLC column, using the same organic acid method for verification of purity. The fractions were analysed using an Agilent 1290 Infinity LC system that was attached to an Agilent 6520 Accurate-Mass Q-TOF mass spectrometer of dual ESI sources (Agilent Technologies, Santa Clara, CA, USA). This analysis was carried out at the School of Medicine and Health Sciences, Monash University Sunway Campus, Malaysia. The chromatographic column used for separation was an Agilent Zorbax SB-C18 NarrowBore $(2.1 \times 150 \mathrm{~mm}, 3.5 \mu \mathrm{m})$ from Agilent Technologies, Santa Clara, CA, USA. The mobile phase was $90 \%$ acetonitrile, with $0.1 \%$ formic acid in water that was carried out isocratically at a flow rate of $0.5 \mathrm{~mL} / \mathrm{min}$, and an injection volume of $1 \mu \mathrm{L}$.

\subsection{Consumer acceptance}

A 9-point hedonic scale was used to determine the acceptability and consumer preference of the ikan pekasam samples. A total of fifty untrained Malaysian panellists who were familiar with ikan pekasam and had previously consumed ikan pekasam were randomly selected in the evaluation process. The six attributes, which were the overall appearance, aroma, level of saltiness and sourness, firmness and acceptability were used for the evaluation. The panellists were asked to evaluate each attribute using a scale ranging from " 1 , dislike extremely" to "9, like extremely" while the cutoff point was at 5 (Heymann and Lawless, 2013; Civille and Carr, 2015). Samples were randomly selected, prepared and coded with a three-digit random number and evaluated by the panellists in the Sensory Evaluation Laboratory, Faculty of Food Science and Technology, Universiti Putra Malaysia that was equipped with individual tasting booths in a conducive environment for testing.

Before presenting the ikan pekasam to the panellists, 
fish samples and a coat of ground roasted rice (weighing $150 \pm 10 \mathrm{~g}$ ) were fried at $170 \pm 2^{\circ} \mathrm{C}$ (the average temperature at the point of dipping the sample into the oil) for six minutes in $1.2 \mathrm{~L}$ of refined, bleached and deodorised (RBD) palm olein (Cap Buruh, Lam Soon Edible Oils, Kuala Lumpur, Malaysia) in a deep fryer (Philips HD 6158/55, $300 \mathrm{~mm} \times 265 \mathrm{~mm}$ ). The oil was changed after every two frying cycles. Once fried, the samples were placed on a piece of tissue paper for $5 \mathrm{~min}$ to absorb any oil residue. The samples were then, carefully cut into $20 \mathrm{~g}$ each. Each of these pieces was kept in an individual small round plastic container that was covered and stored at $70^{\circ} \mathrm{C}$ until ready to be served to the panellists. Biscuits (plain crackers) and drinking water at room temperature were provided to the panellists to rinse their mouth after tasting each sample.

\subsection{Statistical analysis}

All statistical analyses were done using one-way analysis of variance (ANOVA). Tukey's multiple range tests were employed to determine the confidence intervals of differences between the means at $\mathrm{p}<0.05$. The linear Pearson correlation was also used to measure the correlation between $\mathrm{pH}$ value, titratable acidity $(\%$ lactic acid), salt concentration, organic acid composition and consumer acceptability. The software for statistical analysis was using Minitab V.1 (Minitab Inc., State College, Pennsylvania, USA).

\section{Results and discussion}

\section{$3.1 \mathrm{pH}$, titratable acidity and salt content}

Three important properties of fish-based fermented food, including ikan pekasam are $\mathrm{pH}$ value, titratable acidity (TA) and salt (Azman, 2014). According to Table 2, $\mathrm{pH}$ values of acid-assisted fermented ikan pekasam made of black tilapia are significantly lower $(\mathrm{p}<0.05)$ than Javanese carp. The results obtained were in agreement with those obtained by Tanasupawat et al.
(1998), who reported that the $\mathrm{pH}$ value of Pla Ra (Thai fermented fish sauce) ranged from $\mathrm{pH} 4.3$ to 5.6. Commercial samples of Som-fug (traditional Thai fermented minced fishcake) were reported to have $\mathrm{pH}$ values ranging from $\mathrm{pH} 4.56$ to 4.60 (Riebroy et al., 2004). Owens and Mendoza (1985) suggested that $\mathrm{pH}$ values should be below 4.5 to 5.0 to inhibit the growth of pathogenic and spoilage bacteria.

In this study, there was no significant difference $(p>0.05)$ found in the TA (expressed as \% lactic acid) between naturally fermented ikan pekasam made of black tilapia and those from Javanese carp (Table 2). However, there was a significant difference $(p<0.05)$ in TA between acid-assisted fermented ikan pekasam from black tilapia and similarly, Javanese carp.

The study also showed that there was no significant difference ( $p>0.05)$ in salt content between naturally and acid-assisted fermented ikan pekasam of both black tilapia and Javanese carp. Moreover, the salt content ranged from 9.3 to $11.5 \%$, which was closed to the high salt batches $(8.9 \%)$ of Plaa-som (traditional Thai fermented freshwater fish) (Paludan-Müller et al., 2002). Ikan pekasam should not contain less than $10 \%$ of salt, as this will lead to spoilage (Malaysian Food Regulation, 1985). However, Paludan-Müller et al. (2002) suggested that the salt content should be higher than $6 \%$ or $7 \%$ to provide an optimal environment for LAB to grow within 4 to 7 days in the fermentation process for Plaa-som.

\subsection{Organic acid composition and content}

Organic acids are naturally present in food products or can be added either directly during the manufacturing process or indirectly during fermentation (Ergönül and Nergiz, 2010) through hydrolysis, biochemical metabolism and microbial activity (Andersson and Hedlund, 1983). Ikan pekasam has undergone lactic acid fermentation, whereby LAB utilizing starch from roasted

Table 2. $\mathrm{pH}$, titratable acidity and salt contents of naturally fermented and acid-assisted fermented ikan pekasam made of black tilapia and Javanese carp

\begin{tabular}{|c|c|c|c|c|c|c|c|}
\hline \multirow{2}{*}{ Type of fish } & & \multicolumn{2}{|c|}{$\mathrm{pH}$} & \multicolumn{2}{|c|}{ TA (as \% lactic acid) } & \multicolumn{2}{|c|}{ Salt Content (\%) } \\
\hline & & Natural & Acid-assisted & Natural & Acid-assisted & Natural & Acid-assisted \\
\hline \multirow{5}{*}{ Black tilapia } & & 4.8 & 4.5 & 1.0 & 1.3 & 9.3 & 11.0 \\
\hline & Mean & $(0.3)^{\mathrm{Aa}}$ & $(0.3)^{\mathrm{Ab}}$ & $(0.2)^{\mathrm{Aa}}$ & $(0.4)^{\mathrm{Aa}}$ & $(2.6)^{\mathrm{Aa}}$ & $(1.5)^{\mathrm{Aa}}$ \\
\hline & Min. & 4.6 & 4.1 & 0.8 & 0.8 & 6.0 & 10.0 \\
\hline & Max. & 5.2 & 4.7 & 1.3 & 1.8 & 12.0 & 13.0 \\
\hline & Median & 4.8 & 4.5 & 0.9 & 1.2 & 10.0 & 10.0 \\
\hline \multirow{5}{*}{ Javanese carp } & & 5.3 & 5.0 & 0.8 & 0.8 & 10.8 & 11.5 \\
\hline & Mean & $(0.5)^{\mathrm{Aa}}$ & $(0.3)^{\mathrm{Aa}}$ & $(0.5)^{\mathrm{Aa}}$ & $(0.3)^{\mathrm{Ba}}$ & $(2.1)^{\mathrm{Aa}}$ & $(3.4)^{\mathrm{Aa}}$ \\
\hline & Min. & 4.7 & 4.7 & 0.4 & 0.3 & 9.3 & 6.3 \\
\hline & Max. & 5.8 & 5.5 & 1.6 & 1.2 & 14.0 & 15.0 \\
\hline & Median & 5.3 & 5.0 & 0.7 & 0.9 & 10.0 & 12.7 \\
\hline
\end{tabular}

TA, Titratable acidity. Figures in parenthesis indicate the standard deviation. Means within each row with the different lower case are significantly $(\mathrm{p}<0.05)$ different. Means within each column with the different upper case are significantly $(\mathrm{p}<0.05)$ different. 

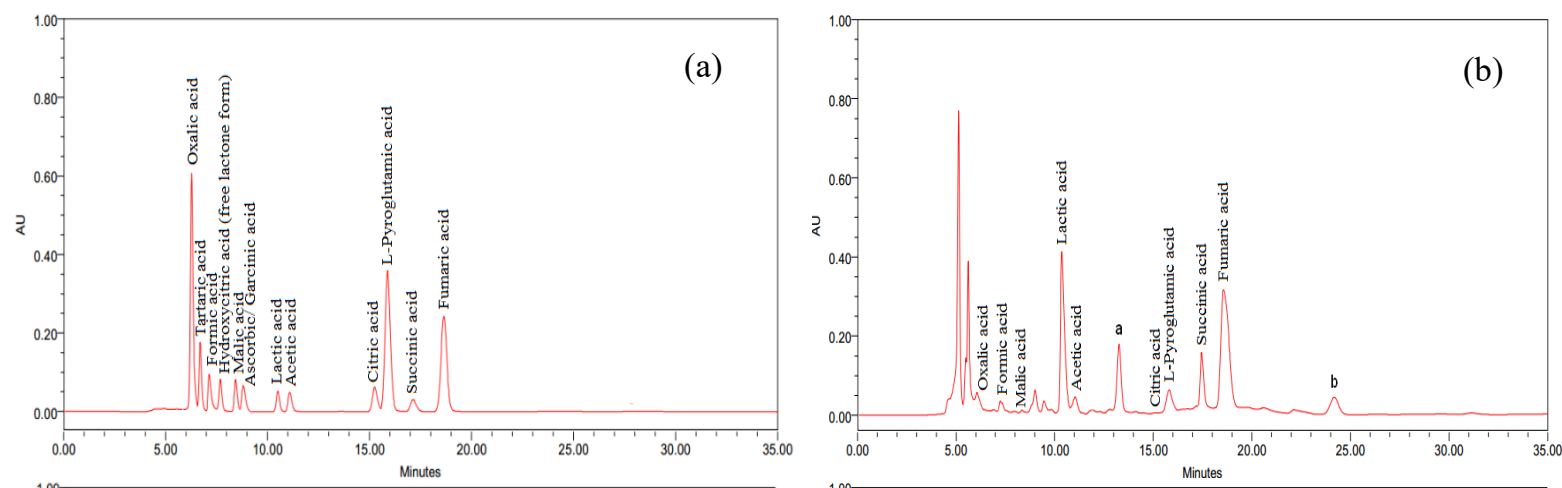

(b)

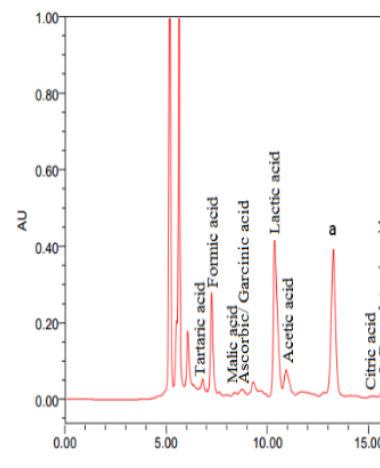

(c)

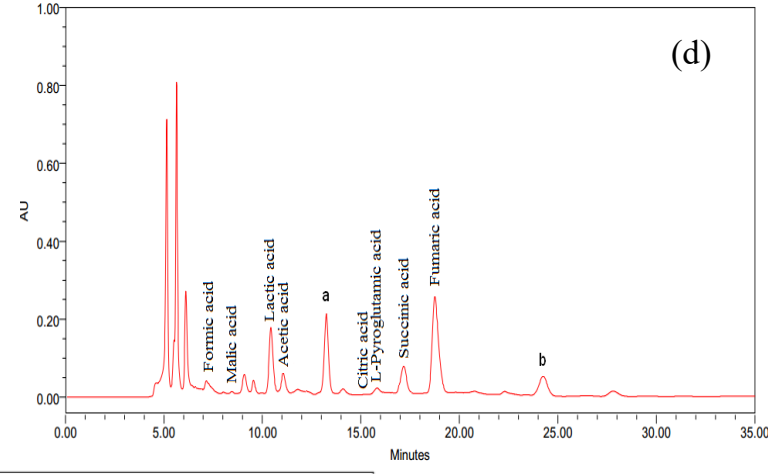

(e)

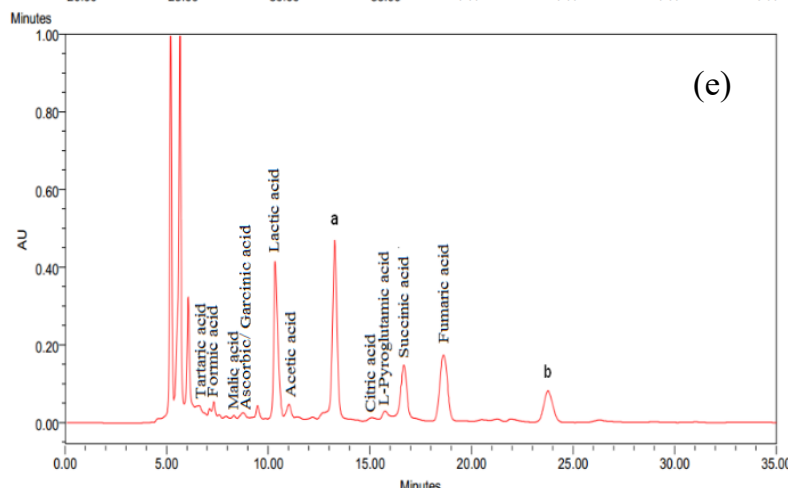

Figure 1. Typical HPLC chromatograms of organic acid standards (a), the organic acid content in naturally fermented ikan pekasam from black tilapia (b), acid-assisted fermented ikan pekasam from black tilapia (c), naturally fermented ikan pekasam from Javanese carp (d), acid-assisted fermented ikan pekasam from Javanese carp (e). Peaks 'a' and 'b' were derived from amino acids and peptides

rice to produce lactic acid (Paludan-Müller et al., 2002; John et al., 2007). Thus, the organic acid profile of this product was analysed. Figure 1(a) illustrated a typical HPLC chromatogram of organic acid standards and Figure 1(b)-(e) showed the representative chromatograms of organic acids in naturally and acidassisted fermented ikan pekasam from black tilapia and Javanese carp. Figure 1(b) illustrated the major organic acid observed in tamarind pulp and had similar findings to Bhadoriya et al. (2011) and Natukunda et al. (2016). Figure 1(c) and (d) demonstrated the primary organic acid in $G$. atroviridis fruit and dried slices of $G$. atroviridis could either be garcinia acid or ascorbic acid, as both had the same retention time (Figure 1(a)). Logically, ascorbic acid should not be found in these dried slices due to possible degradation of the acid during the production of dried G. atroviridis slices. Other organic acids present in the fruit included citric and tartaric acids, while hydroxycitric acid was not detected.

Since the retention time for garcinia acid was similar to that of ascorbic acid, the actual identity of the organic acid represented by the significant peak in $G$. atroviridis fruit was verified through separating the peak, followed by LCMS. Liquid chromatography-mass spectrometry (LCMS) analysis showed that the organic acid that represented the peak was garcinia acid (lactone form), instead of ascorbic acid. Ascorbic acid was not detected in both fractions of fresh and dried samples. This finding was similar to the one reported by Jayaprakasha and Sakariah (2002) as well as Hayamizu et al. (2003), where garcinia acid was the major organic acid detected in the G. atroviridis fruit and dried slices of $G$. atroviridis, with a concentration of 16 to $18 \% \mathrm{w} / \mathrm{w}$.

Table 3 shows that organic acids found in the naturally fermented ikan pekasam samples from both black tilapia and Javanese carp included lactic acid (7.9 to $30.3 \mathrm{mg} / \mathrm{g}$ ), succinic acid (0.9 to $34.1 \mathrm{mg} / \mathrm{g}$ ), acetic acid $(2.7$ to $14.5 \mathrm{mg} / \mathrm{g}$ ), formic acid (0.6 to $11.2 \mathrm{mg} / \mathrm{g}$ ), malic acid (0.3 to $1.6 \mathrm{mg} / \mathrm{g}$ ), oxalic acid (ND to $0.2 \mathrm{mg} /$ g), citric acid (ND to $0.7 \mathrm{mg} / \mathrm{g}$ ), L-pyroglutamic acid ( 0.1 to $0.7 \mathrm{mg} / \mathrm{g}$ ), and fumaric acid (1.9 to $6.2 \mathrm{mg} / \mathrm{g}$ ). The total organic acid content was 43.1 to $51.1 \mathrm{mg} / \mathrm{g}$. 
Table 3. Organic acid contents in naturally and acid-assisted fermented ikan pekasam made of black tilapia and Javanese carp

\begin{tabular}{|c|c|c|c|c|c|c|c|c|c|c|c|c|c|}
\hline \multirow{2}{*}{ Sample } & & \multicolumn{12}{|c|}{ Organic acid content $(\mathrm{mg} / \mathrm{g})$} \\
\hline & & Lac & Tar & Gar & Suc & Ace & For & Mal & Oxa & Cit & L-PGA & Fum & Total \\
\hline \multirow{5}{*}{1} & & 19.7 & & & 11.9 & 7.1 & 6.2 & 0.7 & 0.2 & 0.1 & 0.3 & 4.9 & \\
\hline & Mean & $(8.1)^{\mathrm{a}}$ & ND & ND & $(9.8)^{\mathrm{a}}$ & $(5.7)^{\mathrm{a}}$ & $(4.2)^{\mathrm{a}}$ & $(0.2)^{\mathrm{a}}$ & $(0.0)^{\mathrm{a}}$ & $(0.0)^{\mathrm{a}}$ & $(0.2)^{\mathrm{a}}$ & $(2.0)^{\mathrm{a}}$ & 51.1 \\
\hline & Min. & 14.2 & ND & ND & 1.9 & 3.2 & 1.7 & 0.5 & ND & 0.1 & 0.1 & 2.3 & \\
\hline & Max. & 30.3 & ND & ND & 24.4 & 14.5 & 11.2 & 1 & 0.2 & 0.1 & 0.7 & 6.2 & \\
\hline & Med. & 14.8 & ND & ND & 10.1 & 3.6 & 5.7 & 0.6 & 0.2 & 0.1 & 0.2 & 6.2 & \\
\hline \multirow{5}{*}{2} & & 25.8 & 1 & 0.7 & 16.2 & 6.7 & 6.2 & 0.9 & 0.3 & 0.3 & 0.3 & 3.3 & \\
\hline & Mean & $(10.4)^{\mathrm{a}}$ & $(0.5)^{\mathrm{a}}$ & $(0.0)^{\mathrm{a}}$ & $(10.7)^{\mathrm{a}}$ & $(1.8)^{\mathrm{a}}$ & $(2.0)^{\mathrm{a}}$ & $(0.2)^{\mathrm{a}}$ & $(0.1)^{\mathrm{a}}$ & $(0.1)^{\mathrm{a}}$ & $(0.1)^{\mathrm{a}}$ & $(0.3)^{\mathrm{ab}}$ & 61.1 \\
\hline & Min. & 12.4 & 0.6 & ND & 3.5 & 4.4 & 3.6 & 0.7 & ND & 0.2 & 0.2 & 2.8 & \\
\hline & Max. & 34.4 & 1.7 & 0.7 & 29.1 & 8.7 & 7.7 & 1.2 & 0.4 & 0.4 & 0.4 & 3.5 & \\
\hline & Med. & 30.5 & 0.8 & 0.7 & 17.5 & 7 & 7.2 & 0.9 & 0.3 & 0.3 & 0.3 & 3.3 & \\
\hline \multirow{5}{*}{3} & M & 15 & PID & DID & 17.2 & 5.3 & 1.6 & 0.9 & תI & 0.3 & 0.2 & 2.6 & 1 \\
\hline & Mlean & $(7.0)^{\mathrm{a}}$ & ND & ND & $(13.8)^{\mathrm{a}}$ & $(1.9)^{\mathrm{a}}$ & $(1.0)^{\mathrm{b}}$ & $(0.5)^{\mathrm{a}}$ & ND & $(0.3)^{\mathrm{a}}$ & $(0.1)^{\mathrm{a}}$ & $(0.6)^{\mathrm{b}}$ & 43.1 \\
\hline & Min. & 7.9 & ND & ND & 0.9 & 2.7 & 0.6 & 0.3 & ND & ND & 0.1 & 1.9 & \\
\hline & Max. & 26.2 & ND & ND & 34.1 & 7.6 & 3.1 & 1.6 & ND & 0.7 & 0.4 & 3.4 & \\
\hline & Med. & 13.1 & ND & ND & 17.4 & 5.4 & 1.4 & 0.9 & ND & 0.1 & 0.2 & 2.5 & \\
\hline \multirow{5}{*}{4} & Man & 18.4 & 1 & 1.2 & 12.9 & 5.3 & 1.4 & 0.7 & 0.2 & 0.4 & 0.5 & 3.7 & 157 \\
\hline & Miean & $(9.6)^{\mathrm{a}}$ & $(0.5)^{\mathrm{a}}$ & $(0.6)^{\mathrm{a}}$ & $(9.6)^{\mathrm{a}}$ & $(1.7)^{\mathrm{a}}$ & $(0.3)^{b}$ & $(0.2)^{\mathrm{a}}$ & $(0.1)^{\mathrm{a}}$ & $(0.3)^{\mathrm{a}}$ & $(0.4)^{\mathrm{a}}$ & $(1.7)^{\mathrm{ab}}$ & 45.1 \\
\hline & Min. & 8.5 & 0.5 & ND & 1.6 & 3.4 & 1 & 0.3 & ND & ND & 0.1 & 1.6 & \\
\hline & Max. & 30.1 & 2 & 2 & 25.2 & 7.7 & 1.9 & 1 & 0.4 & 0.2 & 1.3 & 5.9 & \\
\hline & Med. & 16.1 & 0.9 & 1 & 17 & 5.7 & 1.4 & 0.8 & 0.2 & 0.8 & 0.4 & 2.8 & \\
\hline
\end{tabular}

Sample 1, naturally fermented black tilapia; Sample 2, acid-assisted fermented black tilapia; Sample 3, naturally fermented Javanese carp; Sample 4, acid-assisted fermented Javanese carp. Lac, Lactic acid; Tar, Tartaric acid; Gar, Garcinia acid; Suc, Succinic acid; Ace, Acetic acid; For, Formic acid; Mal, Malic acid; Oxa, Oxalic acid; Cit, Citric acid; L-PGA, L-Pyroglutamic acid; Fum, Fumaric acid; Med, Median; ND, Not detected. Figures in parenthesis indicate the standard deviation. Samples sharing the same letter in each column were not significantly different ( $\mathrm{p}>0.05)$

Lactic acid (36.8\%) was the most dominant organic acid found in naturally fermented ikan pekasam, followed by succinic acid (30.9\%), and acetic acid (13.1\%). The presence of acetic and formic acids indicated that the fermentation process was heterofermentative. As expected, tartaric and garcinia acids were not detected since there was no additional tamarind pulp, $G$. atroviridis fruit, or dried slices of $G$. atroviridis into the fermentation process (Table 1).

Table 3 shows lactic acid ( 8.5 to $34.4 \mathrm{mg} / \mathrm{g}$ ) was also the most dominant organic acid in acid-assisted fermented ikan pekasam samples, followed by succinic acid (1.6 to $29.1 \mathrm{mg} / \mathrm{g})$, acetic acid (3.4 to $8.7 \mathrm{mg} / \mathrm{g}$ ) and formic acid (1.0 to $7.7 \mathrm{mg} / \mathrm{g})$. The presence of these acids was indicative of heterofermentative. The presence of tartaric acid ( 0.5 to $2.0 \mathrm{mg} / \mathrm{g}$ ) and garcinia acid (ND to $2.0 \mathrm{mg} / \mathrm{g}$ ) confirmed the addition of tamarind and $G$. atroviridis dried fruit slices during the fermentation process. The total organic acid content in acid-assisted fermented ikan pekasam samples was significantly $(\mathrm{p}<0.05)$ higher $(45.7$ to $61.7 \mathrm{mg} / \mathrm{g})$ than naturally fermented ikan pekasam samples (43.1 to $51.1 \mathrm{mg} / \mathrm{g}$ ). Moreover, the lactic acid content in acid-assisted fermented ikan pekasam (18.4 to $25.8 \mathrm{mg} / \mathrm{g}$ ) was relatively higher than naturally fermented ikan pekasam (15.0 to $19.7 \mathrm{mg} / \mathrm{g}$ ).
As shown in Figure 1(b)-(d), there were dual peaks, ' $a$ ' and ' $b$ ', which were derived from amino acids and peptides, absorbed at $210 \mathrm{~nm}$ (Ezzat et al., 2015). The production of lactic acid and other organic acids such as succinic and acetic acids indicated that during fermentation, the carbon source in ikan pekasam (primarily ground roasted rice) was used by LAB through heterofermentative metabolic pathways. The LAB converted most of the available carbohydrates to lactic acid, with small amounts of acetic acid that resulted in a decline of the $\mathrm{pH}$ value (Tanasupawat and Komagata, 1995). The low $\mathrm{pH}$ during fermentation inhibits the growth of other undesirable microorganisms (National Research Council, 1992).

Generally, the combination of low $\mathrm{pH}$ and organic acid (mainly lactic acid) was the main preservation factor in fermented fish products (Owens and Mendoza, 1985). However, the acid content in some samples did not correlate well with the decreased $\mathrm{pH}$, probably due to the differences in buffering capacity of muscle proteins (Sikorski et al., 1990) or different indigenous microflora (Østergaard et al., 1998; Jeyaram et al., 2009). Moreover, the amount of lactic acid produced during fermentation was also related to the salt content, as observed by Saisithi et al. (1986), whereby Som-fug with a low salt content showed high acid formation. 
Lactic acid was responsible for the souring and ripening of fermented food, which was also the major organic acid detected in fermented salmon fish sauce. In contrast, low contents of acetic acid, malic acid and succinic acid were detected during fermentation (Indoh et al., 2006). Although lactic acid was the major organic acid in commercial Som-fug, fermentable carbohydrate produced from freshwater fish was found to be the main reason for the flavour of Som-fug (Østergaard et al., 1998; Riebroy et al., 2004). Acetic acid was higher in fish sauce (Lopetcharat et al., 2001), while lactic acid was higher in ikan pekasam.

\subsection{Sensory properties}

Selected sensory properties of the ikan pekasam samples were determined using a 9-point hedonic scale. The mean scores for overall acceptability and appearance, aroma, sourness, saltiness, and firmness are shown in Table 4. The results suggested that naturally fermented ikan pekasam made of Javanese carp, Sample $\mathrm{K}$, was the most preferred with the highest score of 6.9. Sample K showed significant higher $(\mathrm{p}<0.05)$ of overall acceptability compared to the sample of naturally fermented ikan pekasam Sample C made of black tilapia, acid-assisted fermented ikan pekasam Sample E made of black tilapia, and acid-assisted fermented ikan pekasam Sample H, M, and O made of Javanese carp. On the other hand, naturally fermented ikan pekasam; Sample $\mathrm{C}$, was overall the least preferred by panellists.
Regardless of the method of the fermentation process used, ikan pekasam made of Javanese carp had higher overall acceptability, whereas $67 \%$ of the score was more than the cut-off point (score of 5), as compared to black tilapia.

In terms of overall appearance acceptability, naturally fermented ikan pekasam from black tilapia, Sample $\mathrm{C}$ was the most preferred and had shown a significant difference $(\mathrm{p}<0.05)$ from Sample B, which was naturally fermented ikan pekasam made of black tilapia. The appearance of Sample E was the least acceptable (score of 3.3), and much lower than the cutoff score of 5. This result may be due to the possible over fermented stage in Sample E, which softened the texture and crumbled when deep-fried. There is no significant difference $(p>0.05)$ in appearance acceptability for other ikan pekasam made of black tilapia and Javanese carp samples, although different fermentation processes were used.

The panellists preferred the aroma from naturally fermented ikan pekasam made of black tilapia, Sample F, which had a significant difference $(\mathrm{p}<0.05)$ with Sample $\mathrm{B}$ and $\mathrm{C}$ that were naturally fermented ikan pekasam made of black tilapia. Moreover, acid-assisted fermented ikan pekasam made of black tilapia, Sample E, showed the least preferred sample among the panellists with the aroma acceptability score of 4.9, which was lower than the cut-off score of 5. Overall, there was no correlation

Table 4. Acceptability scores of naturally and acid-assisted fermented ikan pekasam made of black tilapia and Javanese carp using 9-points hedonic scale

\begin{tabular}{|c|c|c|c|c|c|c|}
\hline \multirow{2}{*}{ Ikan pekasam samples } & \multicolumn{6}{|c|}{ Sensory Attributes } \\
\hline & \multicolumn{2}{|c|}{ Overall acceptability Overall appearance } & \multirow[t]{2}{*}{ Aroma } & \multirow[t]{2}{*}{ Sourness } & \multirow[t]{2}{*}{ Saltiness } & \multirow[t]{2}{*}{ Hardness } \\
\hline Naturally fermented & & & & & & \\
\hline Black tilapia 'B' & $5.8(1.8)^{\mathrm{abc}}$ & $5.7(1.7)^{\mathrm{cde}}$ & $5.2(2.1)^{\mathrm{cd}}$ & $5.7(1.6)^{\mathrm{abc}}$ & $5.4(1.7)^{\mathrm{abc}}$ & $6.0(1.7)^{\mathrm{ab}}$ \\
\hline Black tilapia ' $C$ ' & $5.2(1.9)^{\mathrm{c}}$ & $7.7(1.2)^{\mathrm{a}}$ & $5.4(1.9)^{\mathrm{bcd}}$ & $5.5(1.9)^{\mathrm{abc}}$ & $5.5(2.1)^{\mathrm{ab}}$ & $5.4(1.9)^{\mathrm{b}}$ \\
\hline Black tilapia 'F' & $6.5(1.8)^{\mathrm{abc}}$ & $6.9(1.3)^{\mathrm{abc}}$ & $7.1(1.2)^{\mathrm{a}}$ & $6.4(1.5)^{\mathrm{abc}}$ & $6.5(1.5)^{\mathrm{a}}$ & $6.3(1.4)^{\mathrm{ab}}$ \\
\hline Javanese carp 'I' & $6.8(1.6)^{\mathrm{ab}}$ & $6.6(1.7)^{\mathrm{abcd}}$ & $6.5(1.6)^{\mathrm{abc}}$ & $6.6(1.3)^{\mathrm{ab}}$ & $6.2(1.9)^{\mathrm{ab}}$ & $6.6(1.6)^{\mathrm{ab}}$ \\
\hline Javanese carp ' $\mathrm{K}$ ' & $6.9(1.4)^{\mathrm{a}}$ & $7.1(1.2)^{\mathrm{ab}}$ & $6.6(1.8)^{\mathrm{abc}}$ & $6.7(1.5)^{\mathrm{a}}$ & $6.7(1.6)^{\mathrm{a}}$ & $6.8(1.7)^{\mathrm{a}}$ \\
\hline Javanese carp 'L' & $6.2(1.7)^{\mathrm{abc}}$ & $6.3(1.5)^{\mathrm{abcde}}$ & $5.6(1.9)^{\mathrm{abcd}}$ & $6.0(1.9)^{\mathrm{abc}}$ & $6.1(1.6)^{\mathrm{ab}}$ & $6.3(1.5)^{\mathrm{ab}}$ \\
\hline Javanese carp 'N' & $6.2(1.6)^{\mathrm{abc}}$ & $6.2(1.8)^{\text {bcde }}$ & $6.2(1.5)^{\mathrm{abcd}}$ & $5.9(1.9)^{\mathrm{abc}}$ & $5.8(1.7)^{\mathrm{ab}}$ & $6.1(1.7)^{\mathrm{ab}}$ \\
\hline \multicolumn{7}{|l|}{ Acid-assisted fermented } \\
\hline Black tilapia 'A' & $6.1(1.3)^{\mathrm{abc}}$ & $5.7(1.5)^{\mathrm{cde}}$ & $5.9(1.5)^{\mathrm{abcd}}$ & $5.9(1.4)^{\mathrm{abc}}$ & $5.4(1.6)^{\mathrm{abc}}$ & $6.4(1.6)^{\mathrm{ab}}$ \\
\hline Black tilapia 'D' & $5.6(1.8)^{\mathrm{abc}}$ & $6.5(1.1)^{\mathrm{abcde}}$ & $6.2(1.3)^{\mathrm{abcd}}$ & $5.1(1.8)^{\mathrm{c}}$ & $5.5(2.0)^{\mathrm{abc}}$ & $6.2(1.4)^{\mathrm{ab}}$ \\
\hline Black tilapia 'E' & $5.4(1.8)^{\mathrm{bc}}$ & $3.3(1.9)^{\mathrm{f}}$ & $4.9(2.1)^{\mathrm{d}}$ & $5.2(1.8)^{\mathrm{bc}}$ & $5.5(1.7)^{\mathrm{abc}}$ & $5.9(1.4)^{\mathrm{ab}}$ \\
\hline Javanese carp ' $G$ ' & $6.8(1.1)^{\mathrm{ab}}$ & $7.4(1.1)^{\mathrm{ab}}$ & $6.8(1.3)^{\mathrm{ab}}$ & $6.4(1.4)^{\mathrm{abc}}$ & $6.2(1.6)^{\mathrm{ab}}$ & $6.0(1.8)^{\mathrm{ab}}$ \\
\hline Javanese carp 'H' & $5.3(1.7)^{\mathrm{c}}$ & $5.5(1.5)^{\mathrm{de}}$ & $5.8(1.3)^{\mathrm{abcd}}$ & $5.4(1.8)^{\mathrm{abc}}$ & $4.0(2.0)^{\mathrm{c}}$ & $6.1(1.4)^{\mathrm{ab}}$ \\
\hline Javanese carp 'J' & $6.7(1.2)^{\mathrm{ab}}$ & $6.6(1.7)^{\mathrm{abcd}}$ & $6.0(1.7)^{\mathrm{abcd}}$ & $6.3(1.4)^{\mathrm{abc}}$ & $6.6(1.3)^{\mathrm{a}}$ & $6.3(1.5)^{\mathrm{ab}}$ \\
\hline Javanese carp 'M' & $5.4(1.6)^{\mathrm{bc}}$ & $5.2(1.9)^{\mathrm{e}}$ & $6.3(1.7)^{\mathrm{abcd}}$ & $5.2(1.5)^{\mathrm{bc}}$ & $5.3(1.7)^{\mathrm{abc}}$ & $5.9(1.7)^{\mathrm{ab}}$ \\
\hline Javanese carp 'O' & $5.3(1.9)^{\mathrm{c}}$ & $6.8(1.8)^{\mathrm{abcd}}$ & $5.6(2.4)^{\mathrm{abcd}}$ & $5.1(2.0)^{\mathrm{c}}$ & $4.8(2.1)^{\mathrm{bc}}$ & $5.8(1.7)^{\mathrm{ab}}$ \\
\hline
\end{tabular}

Figures in parenthesis indicate the standard deviation. Samples sharing the same letter in each column were not significantly different $(\mathrm{p}>0.05)$. A score of ' 5 ' represents the minimum level of acceptability. 
found between the aroma acceptability of ikan pekasam, types of fish and fermentation processes used.

The sourness (acidity) of naturally fermented ikan pekasam, Sample K, made of Javanese carp, was the most preferred. However, Sample $\mathrm{K}$ showed no significant difference $(p>0.05)$ with other samples except for acid-assisted fermented ikan pekasam, Sample D and E, made of black tilapia and acid-assisted fermented ikan pekasam, Sample M and O, made of Javanese carp. The panellists gave both Sample D and O the same score of 5.1, which were the lowest score for sourness acceptability. Nonetheless, the results showed that there was no correlation between the sourness acceptability, types of fish used and fermentation processes.

The saltiness of naturally fermented ikan pekasam, Sample F and K, made of black tilapia, and Javanese carp, respectively, and acid-assisted fermented ikan pekasam, Sample J, made of Javanese carp, were the most preferred by the panellists. However, all these samples had no significant difference $(p>0.05)$ with other ikan pekasam samples except for the acid-assisted fermented ikan pekasam, Sample $\mathrm{O}$ and $\mathrm{H}$, made of Javanese carp. The acid-assisted fermented ikan pekasam, Sample $\mathrm{H}$ that was made of Javanese carp, had the lowest acceptability (score of 4.8), most probably because the specific sample had the highest salt content $(14.0 \%)$.

In terms of firmness (texture of fish meat), the naturally fermented ikan pekasam made of Javanese carp, Sample K, was the most preferred by the panellists. However, there was no correlation detected between the firmness of ikan pekasam, fish types and fermentation processes used.

\section{Conclusion}

In this study, the total organic acid content in samples of acid-assisted fermented ikan pekasam is significantly higher $(p<0.05)$ than samples from the naturally fermented ikan pekasam. The addition of tamarind pulp and/or dried slices of G. atroviridis assist the fermentation processes by lowering the $\mathrm{pH}$ values, thus produced a higher lactic acid content compared to natural fermentation. Results have also shown that the fish used to make ikan pekasam went through heterofermentative fermentation, with lactic acid being the dominant organic acid detectable while other acids are being produced. The acid-assisted samples are proven to be accurate as tartaric acid and/or garcinia acid could be identified in these samples.

Except for the overall appearance and aroma acceptability of ikan pekasam, Sample E, made of black tilapia, the panellists found all samples acceptable for overall sourness, saltiness and firmness. The panellists also preferred ikan pekasam fermented both naturally and acid-assisted made of Javanese carp. Unsolicited responses from the panellists indicated that this could be due to Javanese carp having a more tender flesh/muscle texture than black tilapia.

\section{Conflict of interest}

The authors declare no conflict of interest.

\section{Acknowledgments}

We would like to acknowledge the support provided by the Department of Fisheries, Ministry of Agriculture and Agro-based Industry, Malaysia, in identifying producers of ikan pekasam in the country. Also, we are grateful to Universiti Putra Malaysia for a research grant (UPM.RMC.800-3/3/1/GP-IPM/2020/9691100) awarded to Ezzat, M.A.

\section{References}

Agyei, D., Owusu-Kwarteng, J., Akabanda, F. and Akomea-Frempong, S. (2020). Indigenous African fermented dairy products: Processing technology, microbiology and health benefits. Critical Reviews in Food Science and Nutrition, 60(6), 991-1006. https:// doi.org/10.1080/10408398.2018.1555133

Andersson, R. and Hedlund, B. (1983). HPLC analysis of organic acids in lactic acid fermented vegetables. Zeitschrift fur Lebensmittel-Untersuchung undForschung, 176(6), 440. https://doi.org/10.1007/ BF01042558

Association of Official Analytical Chemists (AOAC). (2010). Official Methods of Analysis. 18th Ed. USA: Washington DC.

Azman, E.M. (2014). Characterisation of Local Ikan Pekasam and Development of Process for Production of Ikan Pekasam from Black Pomfret (Parastromateus Niger Bloch). Malaysia: Universiti Putra Malaysia. PhD dissertation.

Bhadoriya, S.S., Ganeshpurkar, A., Narwaria, J., Rai, G. and Jain, A.P. (2011). Tamarindus indica: Extent of explored potential. Pharmacognosy Reviews, 5(9), 73-81. https://doi.org/10.4103/0973-7847.79102

Civille, G.V. and Carr, B.T. (2015). Sensory evaluation techniques. USA: CRC Press. https:// doi.org/10.1201/b19493

Department of Fisheries Malaysia. December (2014). Fermented Fish. Retrieved on April 16, 2020 from Department of Fisheries Malaysia Website: https:// www.dof.gov.my/index.php/pages/view/146 
Ergönül, P.G. and Nergiz, C. (2010). Determination of organic acids in olive fruit by HPLC. Czech Journal of Food Sciences, 28, 202-205. https:// doi.org/10.17221/1379-CJFS

Ezzat, M.A., Zare, D., Karim, R. and Ghazali, H.M. (2015). Trans-and cis-urocanic acid, biogenic amine and amino acid contents in ikan pekasam (fermented fish) produced from Javanese carp (Puntius gonionotus) and black tilapia (Oreochromis mossambicus). Food Chemistry, 172, 893-899. https://doi.org/10.1016/j.foodchem.2014.09.158

Hayamizu, K., Ishii, Y., Kaneko, I., Shen, M., Okuhara, Y., Shigematsu, N., Tomi, H., Furuse, M., Yoshino, G. and Shimasaki, H. (2003). Effects of Garcinia cambogia (Hydroxycitric Acid) on visceral fat accumulation: a double-blind, randomized, placebocontrolled trial. Current Therapeutic Research, 64 (8), 551-567. https://doi.org/10.1016/ j.curtheres.2003.08.006

Heymann, H. and Lawless, H.T. (2013). Sensory evaluation of food: principles and practices. USA: Springer Science and Business Media. https:// doi.org/10.1007/978-1-4419-6488-5

$\mathrm{Hu}$, Y., Xia, W. and Liu, X. (2007). Changes in biogenic amines in fermented silver carp sausages inoculated with mixed starter cultures. Food Chemistry, 104(1), 188-195.

https://doi.org/10.1016/ j.foodchem.2006.11.023

Indoh, K., Nagata, S., Kanzaki, K., Shiiba, K. and Nishimura, T. (2006). Comparison of characteristics of fermented salmon fish sauce using wheat gluten koji with those using soy sauce koji. Food Science and Technology Research, 12(3), 206-212. https:// doi.org/10.3136/fstr.12.206

Jayaprakasha, G.K. and Sakariah, K.K. (2002). Determination of organic acids in leaves and rinds of Garcinia indica (Desr.) by LC. Journal of Pharmaceutical and Biomedical Analysis, 28(2), 379 -384. https://doi.org/10.1016/S0731-7085(01)006239

Jeyaram, K., Singh, T.A., Romi, W., Devi, A.R., Singh, W.M., Dayanidhi, H., Singh, N.R. and Tamang, J.P. (2009). Traditional fermented foods of Manipur. Indian Journal of Traditional Knowledge, 8(1), 115121.

John, R.P., Nampoothiri, K.M. and Pandey, A. (2007). Fermentative production of lactic acid from biomass: an overview on process developments and future perspectives. Applied Microbiology and Biotechnology, 74(3), 524-534. https:// doi.org/10.1007/s00253-006-0779-6

Lehane, L. and Olley, J. (2000). Histamine fish poisoning revisited. International Journal of Food Microbiology, 58(1-2), 1-37. https://doi.org/10.1016/ S0168-1605(00)00296-8

Litchfield, J.H. (1996). Microbiological production of lactic acid. In Advances in applied microbiology. Vol. 42, p. 45-95. USA: Academic Press. https:// doi.org/10.1016/S0065-2164(08)70372-1

Lopetcharat, K., Choi, Y.J., Park, J.W. and Daeschel, M.A. (2001). Fish sauce products and manufacturing: a review. Food Reviews International, 17(1), 65-88. https://doi.org/10.1081/ FRI-100000515

Malaysian Food Regulation. (1985). Part VIII Standards and Particular Labelling Requirements For Food: Pekasam. Retrieved on April 16, 2020 from Food Safety Information System of Malaysia: http:// fsis2.moh.gov.my/fosimtestsite/HOM/ frmHOMFARSec .aspx $? \mathrm{id}=21$.

National Research Council. (1992). Applications of Biotechnology in Traditional Fermented Foods. USA: Washington, DC. https:// doi.org/10.17226/1939

Natukunda, S., Muyonga, J.H. and Mukisa, I.M. (2016). Effect of tamarind (Tamarindus indica L.) seed on antioxidant activity, phytocompounds, physicochemical characteristics, and sensory acceptability of enriched cookies and mango juice. Food Science and Nutrition, 4(4), 494-507. https:// doi.org/10.1002/fsn3.311

Østergaard, A., Embarek, P.K.B., Wedell-Neergaard, C., Huss, H.H. and Gram, L. (1998). Characterization of anti-listerial lactic acid bacteria isolated from Thai fermented fish products. Food Microbiology, 15(2), 223-233. https://doi.org/10.1006/fmic.1997.0153

Owens, J.D. and Mendoza, L.S. (1985). Enzymically hydrolysed and bacterially fermented fishery products. International Journal of Food Science and Technology, 20(3), 273-293. https://doi.org/10.1111/ j.1365-2621.1985.tb00378.x

Paludan-Müller, C., Valyasevi, R., Huss, H.H. and Gram, L. (2002). Genotypic and phenotypic characterization of garlic-fermenting lactic acid bacteria isolated from som-fak, a Thai low-salt fermented fish product. Journal of Applied Microbiology, 92(2), 307-314. https:// doi.org/10.1046/j.1365-2672.2002.01544.x

Reddy, G., Altaf, M.D., Naveena, B.J., Venkateshwar, M. and Kumar, E.V. (2008). Amylolytic bacterial lactic acid fermentation-a review. Biotechnology Advances, 26(1), 22-34. https://doi.org/10.1016/ j.biotechadv.2007.07.004

Rhee, S.J., Lee, J.E. and Lee, C.H. (2011). Importance of 
lactic acid bacteria in Asian fermented foods. Microbial Cell Factories, 10, S5. https:// doi.org/10.1186/1475-2859-10-S1-S5

Riebroy, S., Benjakul, S., Visessanguan, W., Kijrongrojana, K. and Tanaka, M. (2004). Some characteristics of commercial Som-fug produced in Thailand. Food Chemistry, 88(4), 527-535. https:// doi.org/10.1016/j.foodchem.2004.01.067

Saisithi, P., Wongkhalaung, C., Boonyaratanakornkit, M., Yongmanitchai, P., Chimanage, P. and Maleehuan, S. (1986). Improvement of a Thai traditional fermented fish product: som-fug. Thailand: Institute of Food Research and Product Development, Kasetsart University.

Sikorski, Z.E., Kołakowska, A. and Burt, J.R. (Eds.) (1990). Postharvest biochemical and microbial changes. In Seafood: Resources, Nutritional Composition, and Preservation. $1^{\text {st }}$ ed., p. 55-75. USA: CRC Press.

Sturm, K., Koron, D. and Stampar, F. (2003). The composition of fruit of different strawberry varieties depending on maturity stage. Food Chemistry, 83(3), 417-422. https://doi.org/10.1016/S0308-8146(03) 00124-9

Tanasupawat, S. and Komagata, K. (1995). Lactic acid bacteria in fermented foods in Thailand. World Journal of Microbiology and Biotechnology, 11(3), 253-256. https://doi.org/10.1007/BF00367094

Tanasupawat, S., Okada, S. and Komagata, K. (1998). Lactic acid bacteria found in fermented fish in Thailand. The Journal of General and Applied Microbiology, 44(3), 193-200. https:// doi.org/10.2323/jgam.44.193

Zaman, M.Z., Bakar, F.A., Jinap, S. and Bakar, J. (2011). Novel starter cultures to inhibit biogenic amines accumulation during fish sauce fermentation. International Journal of Food Microbiology, 145(1), 84-91. https://doi.org/10.1016/

j.ijfoodmicro.2010.11.031

Zare, D., Muhammad, K., Bejo, M.H. and Ghazali, H.M. (2013). Changes in urocanic acid, histamine, putrescine and cadaverine levels in Indian mackerel (Rastrelliger kanagurta) during storage at different temperatures. Food Chemistry, 139(1-4), 320-325. https://doi.org/10.1016/j.foodchem.2012.12.040

Zare, D., Muhammad, K., Bejo, M.H. and Ghazali, H.M. (2015). Determination of urocanic acid, a compound implicated in histamine toxicity, and assessment of biogenic amines relative to urocanic acid content in selected fish and fish products. Journal of Food Composition and Analysis, 37, 95-103. https:// doi.org/10.1016/j.jfca.2014.06.014 